Article

\title{
Enabling Renewable Energy While Protecting Wildlife: An Ecological Risk-Based Approach to Wind Energy Development Using Ecosystem-Based Management Values
}

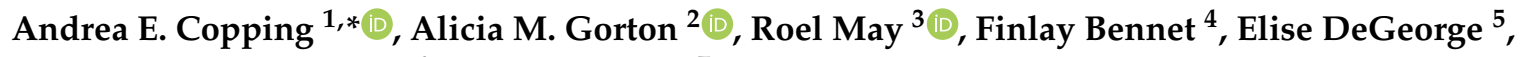 \\ Miguel Repas Goncalves ${ }^{6}$ and Bob Rumes ${ }^{7}$ \\ 1 Pacific Northwest National Laboratory, 1100 Dexter Ave N \#500, Seattle, WA 98109, USA \\ 2 Pacific Northwest National Laboratory, 902 Battelle Blvd, Richland, WA 99352, USA; alicia.gorton@pnnl.gov \\ 3 Norwegian Institute for Nature Research, Høgskoleringen 9, 7034 Trondheim, Norway; roel.may@nina.no \\ 4 Marine Scotland, St. Andrew's House, Regent Road, Edinburgh EH1 3DG, UK; finlay.bennet@gov.scot \\ 5 National Renewable Energy Laboratory, 18200 CO-128, Boulder, CO 80303, USA; elise.degeorge@nrel.gov \\ 6 STRIX, Rua Roberto Ivens, $13141^{\circ}$ sala 15, 4450-251 Matosinhos, Portugal; miguel.repas@strix.pt \\ 7 Royal Belgian Institute of Natural Sciences, Vautier Street 29, 1000 Brussels, Belgium; \\ brumes@naturalsciences.be \\ * Correspondence: andrea.copping@pnnl.gov
}

Received: 19 October 2020; Accepted: 9 November 2020; Published: 11 November 2020

\begin{abstract}
Acceptance of wind energy development is challenged by stakeholders' concerns about potential effects on the environment, specifically on wildlife, such as birds, bats, and (for offshore wind) marine animals, and the habitats that support them. Communities near wind energy developments are also concerned with social and economic impacts, as well as impacts on aesthetics, historical sites, and recreation and tourism. Lack of a systematic, widely accepted, and balanced approach for measuring the potential damage to wildlife, habitats, and communities continues to leave wind developers, regulators, and other stakeholders in an uncertain position. This paper explores ecological risk-based management (RBM) in wind energy development for land-based and offshore wind installations. This paper provides a framework for the adaptation of ecosystem-based management to wind energy development and examines that framework through a series of case studies and best management practices for applying risk-based principles to wind energy. Ten case studies indicate that wind farm monitoring is often driven by regulatory requirements that may not be underpinned by scientific questions. While each case applies principles of adaptive management, there is room for improvement in applying scientific principles to the data collection and analysis. Challenges and constraints for wind farm development to meet RBM framework criteria include collecting sufficient baseline and monitoring data year-round, engaging stakeholder facilitators, and bringing together large and diverse scientific teams. The RBM framework approach may provide insights for improved siting and consenting/permitting processes for regulators and their advisors, particularly in those nations where wind energy is still in the early development stages on land or at sea.
\end{abstract}

Keywords: wind energy; risk-based management; ecosystem-based management; risk assessment; best management practices

\section{Introduction}

Widespread use of wind energy to power human needs can help to mitigate two of the greatest threats to the environment: global climate change and effects of direct anthropogenic encroachment 
on the natural world [1]. However, the development and operation of land-based and offshore wind energy farms have the potential to cause direct and indirect harm to wildlife and the habitats they require. Increasingly the greatest challenge facing development of wind energy on land and at sea is not technical, financial, or limited by the wind resource. Rather, stakeholder acceptance and regulatory permission are seen as hurdles based on concerns about effects on birds, bats, and terrestrial mammals, as well as marine mammals, sea turtles, and some fish at sea. Other issues of concern to communities near wind energy developments include social and economic impacts, as well as impacts on cultural and social values such as aesthetics, historical sites, and recreational and tourism activities [2,3].

This paper seeks to apply risk-based approaches to manage the interactions of wind energy development and wildlife conservation. The most common risks and challenges for managing wind and wildlife interactions will be reviewed, and the range of potential risk-based systems discussed as background to the development of a framework and criteria for applying such a management scheme.

\subsection{Ecological Risks Posed by Wind Energy Development}

The range of potential risks from land-based wind farms to wildlife and habitats is well documented, while less is known about risks from offshore wind [4-7]. Risks include collision risk to birds and bats [8-10], displacement of flying and terrestrial animals from preferred habitats [11,12], and disruption of migratory corridors [13,14], particularly for terrestrial mammals [15]. The direct and indirect effects from offshore wind farm development have been less well documented, but they include similar risks to bird and bat collisions [16,17]; disruption of marine mammal corridors [15] as well as harm to marine mammals, fish, and sea turtles from construction of bottom-mounted turbine towers [18]; the potential for scour and sediment resuspension around the foundations of bottom-mounted wind turbines [19]; and some evidence of displacement or barrier effects because of the presence of large offshore wind farms [20-22].

\subsection{Challenges of Wind-Wildlife Management}

Lack of a systematic, widely accepted, and balanced approach for measuring the potential damage to wildlife, habitats, and communities continues to leave wind developers, regulators, and other stakeholders in an uncertain position. This uncertainty often leads to regulatory requirements for studies and monitoring programs that do not necessarily contribute to improved environmental protection [23]. Regulatory requirements and data collection efforts around wind farms during construction, operation, and other project phases need to be more consistently linked to the actual risk posed to a range of animals and habitats. One such approach to accomplishing this linkage is risk-based management (RBM), which may act as a decision support system.

\subsection{Risk and Risk-Based Management}

Risk is a term widely used in many contexts; for the purposes of this paper, risk is defined as the potential for a negative outcome and is considered the intersection of the probability (likelihood) of that negative outcome, and the consequence (severity) of the outcome [24]. RBM is broadly defined as a system for the identification, assessment, and setting of priorities among risks, so that the appropriate level of resources can be applied to minimize, monitor, and control deleterious outcomes, considering the inherent uncertainties in the system. Managing risk is a process by which potential negative outcomes can be mitigated so that the residual risks are considered acceptable to society as informed by the identification, evaluation, and monitoring of the mechanisms and outcomes that make up the risks. There are many tools and constructs for identifying and managing risk for wind farms and other industrial developments that may meet the legislative intent for managing development. These resources include International Standards Organisation standard 31,000 [25] and the International Finance Corporation (IFC) Good Practice Handbook for Cumulative Impact Assessment [26], as well as scientific literature on these topics [27-29]. 
RBM is reflected in many private and public sector planning and development actions as well as project planning efforts; some of the lessons learned from other industries are relevant to a risk-based system for examining wind and wildlife interactions [11,30]. A number of risk-based methods have been used for environmental and natural resource management but have not yet gained widespread use in extending protection to wildlife, habitats, and ecosystem processes that might be affected by wind energy development. The most commonly used techniques include comparative risk analysis, multiple-criteria decision-making/multiple-criteria decision analysis [31], multi-attribute utility theory, analytical hierarchy process [31], outranking, ordered weighted averaging, bow tie analysis, cumulative effects analysis, layer of protection analysis, and ecosystem-based management [32].

\subsection{Challenges of Consenting/Permitting Wind Energy Projects}

Despite decades of wind development in many nations, there is still considerable uncertainty around potential effects of wind turbines, particularly offshore, on wildlife and their environment [33-35]. The uncertainty and paucity of data that link wind energy construction and operation to deleterious effects, or that demonstrate no effect, coupled with regulatory drivers, often leads regulators and stakeholders to approach wind energy consenting/permitting processes conservatively, in ways that may be as stringent as the application of the Precautionary Principle [36,37]. Applying such precaution may lead regulators or stakeholders to conclude that birds or bats entering the rotor-swept area of a wind turbine are assumed to be fatally struck by a turbine blade. Mixed into this precautionary approach is the erroneous equating of the potential effects of short-lived (but often high-impact) construction activities, such as pile driving at sea for offshore wind installation, with the ongoing but potentially less dangerous interactions of wind farms and wildlife during operation. Application of the precautionary principle can result in permission being denied for new wind projects when deleterious effects are in dispute or unknown.

Where risk-based approaches have been applied to the construction and operation of wind farms, they have focused on risks other than ecological risks, including technical risk and reliability analyses, financial risks, and security risks [38-41].

\subsection{Environmental Risk-Based Systems for Wind Energy}

Systems for examining environmental risk around wind energy farms have not been applied in a systematic manner for consenting/permitting and there have been few attempts to use risk assessments to determine a proportional level of investment in field data collection for baseline (pre-installation) assessment or post-installation monitoring. Systematic designs of mitigation to provide effective and efficient recourse for environmental impacts are also lacking [35]. There are some limited examples of risk-based systems for wind energy development:

- Marine Scotland, the regulator for offshore energy development in Scotland, employs the Survey-Deploy-Monitor approach to allow accelerated permitting and licensing for low-risk areas. This risk-based approach is used when potential effects are poorly understood to enable wind turbine deployment in a manner that will reduce scientific uncertainty over time, while enabling a level of development that is proportionate to the risks [42].

- A risk-ranking system developed in the U.S. considers the biological imperatives for the potential effects of offshore wind development on marine animals, birds, and bats, and their associated habitats; the system also considers the protected or management status for each set of organisms in the U.S. [43]. However, the system has not been implemented for permitting/consenting wind farms in the U.S. or internationally.

- Adaptive management (AM) - a learning-based management approach used to reduce scientific uncertainty — has been identified as a tool for advancing the wind energy industry, but its practical application has been limited. AM has primarily been actively implemented in the U.S., while other nations have applied some AM principles. AM allows wind energy projects to adapt monitoring and mitigation over time, leading to improved decision-making [34,44]. 


\subsection{Ecosystem-Based Management}

While many risk-based approaches used by other industries to manage natural resources provide useful insights into managing wind energy and wildlife interactions, few touch on all of the important aspects of ecosystems that land-based and offshore wind encompass. The risk-based approach that most closely addresses aspects of the complex ecosystems that make up the landscapes/seascapes of wind energy development is ecosystem-based management (EBM), used primarily in managing fisheries and the marine environment $[45,46]$. EBM takes into account human as well as environmental/ecological factors, using approaches that embrace holistic methods to include humans in an integrated view of managing resources while sustaining ecological integrity [47-49]. EBM has been applied in several nations to manage marine systems, notably in the U.S. by the National Oceanic and Atmospheric Administration (NOAA) to inform multi-species, multi-sector ocean management [50-52], and in the European Union (EU) as an integrative policy concept for the protection of aquatic biodiversity [53].

EBM has been used sparingly to study and manage land-based wind energy projects. In Canada, the development of a large land-based wind farm at Aristazabal Island, British Columbia, relied on multi-criteria decision-making based on a geographical information system (GIS) within an EBM framework for siting [54]. Where ecological risk assessments have been applied to land-based wind farms, they appear to focus on estimating wildlife mortality rates, behavioral changes, or interspecific differences in vulnerability, rather than the vulnerability and connectivity of all pertinent ecosystem components. In addition, a few studies have investigated the application of ecological risk assessments on endangered or rare species populations in other nations [55].

\subsection{Effective Application of Ecosystem-Based Management}

There is a gap between the tenets of EBM and its practical application and appearance in management plans [56]. This gap suggests that EBM concepts need to be more effectively translated and that operational tools are needed to translate EBM principles into practice.

The elements of EBM overlap with the ecological goals of protecting wildlife and habitats under wind energy development. This paper explores the use of ecological RBM in land-based and offshore wind energy as a development and management tool, striving to describe a means of reducing the uncertainties in data related to wind energy/wildlife interactions that drive risk to the environment. By examining and managing the potential negative outcomes that may befall birds, bats, terrestrial wildlife, marine mammals, other marine organisms, and the habitats and migratory pathways that support them, RBM has the potential to ensure that wildlife protection measures are focused on the factors that pose the highest actual (as opposed to perceived) risk, while maximizing renewable energy development.

\section{Materials and Methods}

Based on a review of risk management approaches and the wind development needs of international regulators, project developers, and researchers, EBM was chosen as the most appropriate risk-based tool upon which to develop a wind-wildlife risk-based management framework. The framework was developed using EBM criteria, modified from other RBM techniques applied to other industries and natural resources [32], and adapted to goals and objectives specific to wind energy development. The goals of EBM were reviewed and annotated [56] and formed the basis from which objectives were derived, with the intent of assisting with responsible management of wind farms (Table 1). In developing the objectives for the framework, three central attributes were used to assess potential changes in ecosystems and ecological processes over time (e.g., long-term population trajectories of long-lived species such as bats) at the scale of a wind energy farm [57]:

1. Spatial scales: Where does the risk occur and at what scale? For example, seasonal or diurnal migratory linkages to wind farm development at one location may have an impact farther afield.

2. Temporal scales: When does the impact occur? For example, even though the severity of an impact may appear to be limited now, it may trigger an ecological tipping point for future generations. 
3. Theoretical assessments: Which available models can appropriately assess risk across space and time? For example, economic cost-benefit models tend to poorly predict effects in the long term.

Table 1. Ecosystem-based management criteria derived from the scientific literature (adapted from [56]).

\begin{tabular}{|c|c|c|}
\hline Category & Specific Criteria & Requirement for Specific Criteria \\
\hline \multirow{3}{*}{ General criteria } & Sustainability & $\begin{array}{l}\text { Emphasizes maintenance of one or more aspects of } \\
\text { the ecosystem }\end{array}$ \\
\hline & Ecological health & Includes non-specific goals for ecosystem health or integrity \\
\hline & $\begin{array}{l}\text { Inclusion of humans } \\
\text { in ecosystem }\end{array}$ & $\begin{array}{l}\text { Recognizes that humans are elements of an ecosystem and } \\
\text { their education and well-being are important components of } \\
\text { management decisions }\end{array}$ \\
\hline \multirow{3}{*}{$\begin{array}{l}\text { Specific ecological } \\
\text { criteria }\end{array}$} & Complexity & $\begin{array}{l}\text { Acknowledges that linkages between ecosystem components, } \\
\text { such as food web structure, predator-prey relationships, } \\
\text { habitat associations, and other biotic and abiotic interactions, } \\
\text { should be incorporated into management decisions }\end{array}$ \\
\hline & Temporal & $\begin{array}{l}\text { Incorporates the temporal scale and dynamic character } \\
\text { of ecosystems }\end{array}$ \\
\hline & Spatial & $\begin{array}{l}\text { Recognizes that ecosystem processes operate over a wide } \\
\text { range of spatial scales }\end{array}$ \\
\hline \multirow{3}{*}{$\begin{array}{l}\text { Specific human } \\
\text { dimension criteria }\end{array}$} & $\begin{array}{l}\text { Ecosystem goods } \\
\text { and services }\end{array}$ & $\begin{array}{l}\text { Recognizes that humans use and value natural resources, such } \\
\text { as water quality, harvested products, tourism, and } \\
\text { public recreation }\end{array}$ \\
\hline & Economic & Integrates economic factors into the vision for the ecosystem \\
\hline & Stakeholder & $\begin{array}{l}\text { Engages interested parties in the management planning } \\
\text { processes to find common solutions }\end{array}$ \\
\hline \multirow{8}{*}{$\begin{array}{l}\text { Specific } \\
\text { management } \\
\text { criteria }\end{array}$} & Science-based & $\begin{array}{l}\text { Incorporates management decisions based on } \\
\text { tested hypotheses }\end{array}$ \\
\hline & Boundaries & Recognizes that management plans must be spatially defined \\
\hline & Technological & $\begin{array}{l}\text { Uses scientific and industrial technology as tools needed to } \\
\text { monitor the ecosystem and evaluate management actions }\end{array}$ \\
\hline & Adaptive & $\begin{array}{l}\text { Continues to improve management actions through } \\
\text { systematic evaluation }\end{array}$ \\
\hline & Co-management & $\begin{array}{l}\text { Promotes shared responsibility for management between } \\
\text { multiple levels of government and stakeholders }\end{array}$ \\
\hline & $\begin{array}{l}\text { Precautionary } \\
\text { approach }\end{array}$ & $\begin{array}{l}\text { Manages conservatively when threats to the ecosystem } \\
\text { are uncertain }\end{array}$ \\
\hline & Interdisciplinary & $\begin{array}{l}\text { Bases management on scientific understanding from several } \\
\text { disciplines (ecology, economics, sociology) }\end{array}$ \\
\hline & Monitoring & $\begin{array}{l}\text { Tracks changes in biotic, abiotic, and human ecosystem } \\
\text { components for management purposes }\end{array}$ \\
\hline
\end{tabular}

This framework has been developed and tested empirically using a set of case studies of land-based and offshore wind. The wind energy farms chosen as case studies represent a small subset of existing farms where there is clear intent to examine and maintain environmental integrity by protecting wildlife populations, ensure the continuance of adequate habitat, and/or conserve ecosystem functions and services. The case studies do not attempt to scientifically assess the range of wind energy farms that are in development or operation around the world, but rather to identify risks posed by wind farms during multiple phases of development, to establish criteria for evaluating the acceptability of those ecological risks, and to develop best practices for implementing RBM for wind energy development. 


\section{Results}

The RBM framework for wind-wildlife consists of a series of goals and objectives against which empirical measures of wind energy farm management can be assessed. Derived from the EBM criteria (Table 1), the goals that showed the closest correlation to wind energy management were honed with wind-wildlife specific objectives (Table 2).

Table 2. Framework for ecological risk-based management as it applies to wind energy development, derived from the goals of ecosystem-based management, after [56].

\begin{tabular}{|c|c|c|}
\hline Goal No. & Goal & Wind Farm Objectives Needed to Meet Risk-Based Management Goals \\
\hline 1 & Sustainability & $\begin{array}{l}\text { Native animals, plants, and the habitats and migratory corridors that } \\
\text { support them must persist and take into account population-level effects. }\end{array}$ \\
\hline 2 & Ecological health & $\begin{array}{l}\text { The health and resiliency of the overall ecosystem is maintained or } \\
\text { enhanced through management actions. }\end{array}$ \\
\hline 3 & $\begin{array}{l}\text { Inclusion of humans } \\
\text { in ecosystem }\end{array}$ & $\begin{array}{l}\text { A range of ecosystem services are accommodated in the area of wind } \\
\text { farm development. }\end{array}$ \\
\hline 4 & Complexity & $\begin{array}{l}\text { Management decisions acknowledge linkages between ecosystem } \\
\text { components, including predator-prey relationships, critical habitat needs } \\
\text { for vulnerable populations, linkages of migratory corridors and critical } \\
\text { habitats, and food web linkages at sea. }\end{array}$ \\
\hline 5 & Temporal & $\begin{array}{l}\text { Post-installation monitoring data collection and mitigation actions are } \\
\text { applied seasonally as needed for key populations. Consideration is given to } \\
\text { long-term cumulative effects on populations and habitats. }\end{array}$ \\
\hline 6 & Spatial & $\begin{array}{l}\text { Baseline assessments and post-installation monitoring of key populations } \\
\text { cover spatial scales appropriate to the life history and home ranges of those } \\
\text { populations. Consideration is given to the effects of wind farms that may } \\
\text { occur at greater distances. }\end{array}$ \\
\hline 7 & Economics & $\begin{array}{l}\text { Operational constraints to protect wildlife and habitat allow sufficient } \\
\text { power generation for wind farms to be profitable. }\end{array}$ \\
\hline 8 & Stakeholders & $\begin{array}{l}\text { Interested parties are consulted at the start of the development process and } \\
\text { at all key points in time to determine sustainable operation of the } \\
\text { wind farm. }\end{array}$ \\
\hline 9 & Science-based & $\begin{array}{l}\text { Management criteria are science-based with hypothesis-based } \\
\text { post-installation monitoring plans. }\end{array}$ \\
\hline 10 & Technological & $\begin{array}{l}\text { Appropriate technologies and scientifically validated methods are used to } \\
\text { monitor the potential effects of wind farm operation, and to assess the } \\
\text { effectiveness of mitigation actions. }\end{array}$ \\
\hline 11 & Adaptive & $\begin{array}{l}\text { Adaptive management principles and procedures are applied to allow } \\
\text { changes in post-installation monitoring efforts and mitigation actions when } \\
\text { monitoring data indicate the need. }\end{array}$ \\
\hline
\end{tabular}

The case studies used to refine and test the framework were chosen from land-based and offshore wind energy farms internationally, based on those for which sufficient information was available, covering a range of development phases from planning, siting, consenting/permitting, installation, operation, maintenance, repowering, and decommissioning. The case studies span several decades of development from older well-established wind farms to those under development, particularly in the offshore area, as well as one long-planned offshore wind farm that failed to progress, and a set of land-based wind farms that have been evaluated as a unit within a region. Each case study is briefly described, including the key management actions taken to protect wildlife (Table 3). More information about each case study can be found in [32].

Each case study has been examined to determine the degree to which it can be seen to meet the RBM goals for the framework, across the development phases for land-based and offshore wind farms (Table 4). 
Table 3. Summary of wind energy farm case studies. Each case study details the location, physical features, development stage, and management actions taken to protect wildlife and habitat. More detail on each case study can be found in [32].

\begin{tabular}{|c|c|c|c|c|c|}
\hline Case & Number and Name & Country & $\begin{array}{l}\text { Description of } \\
\text { Development }\end{array}$ & Stage of Development & Management Actions \\
\hline 1 & $\begin{array}{l}\text { Crudine Ridge } \\
\text { Wind Farm, New } \\
\text { South Wales }\end{array}$ & Australia & $\begin{array}{l}37 \text { turbines, } 135 \mathrm{MW} \\
\text { capacity }\end{array}$ & Under construction & $\begin{array}{l}\text { Ecological approach to management, including adaptive management: } \\
\text { 1. Biodiversity Management Plan developed as part of the overall Environmental } \\
\text { Management Strategy that requires management of brush, plants, and habitat in } \\
\text { the vicinity of wind farms, erosion control measures, brushfire management, and } \\
\text { extensive buffer around wind farms as a biodiversity offset. } \\
\text { 2. Bird and Bat Adaptive Management Plan to provide baseline data on bird and bat } \\
\text { populations, post-installation monitoring, documenting mitigation measures, pest } \\
\text { control to discourage raptors around wind farm, bat deterrence including lighting, } \\
\text { reporting to support adaptive management. } \\
\text { A Risk Evaluation Matrix Model was applied for risk of bird or bat collision or } \\
\text { documented deterrence. }\end{array}$ \\
\hline 2 & $\begin{array}{l}\text { Norther Offshore } \\
\text { Wind Farm }\end{array}$ & Belgium & $\begin{array}{c}44 \text { turbines, } 370 \mathrm{MW} \\
\text { capacity }\end{array}$ & Operational & $\begin{array}{l}\text { 1. Siting: The layout of the wind farm was adapted to minimize navigational and } \\
\text { resultant environmental risk. Obligatory collision-friendly foundation structures } \\
\text { are minimizing the risk of oil spills. } \\
\text { 2. } \begin{array}{l}\text { During construction: Active mitigation was used to reduce the emission of high } \\
\text { levels of impulsive sound during pile driving. The effectiveness of the mitigation } \\
\text { methods was evaluated. }\end{array} \\
\text { 3. Uncertainty and knowledge gaps were addressed as part of an overarching } \\
\text { long-term monitoring program funded by all nine offshore wind farms in } \\
\text { Belgium. Studies include all ecosystem components and their interlinkages. } \\
\text { 4. Multi-use of the area (co-use with either aquaculture or wet renewables) is part of } \\
\text { the licensing conditions. } \\
\text { 5. Adaptive management used to allow for adjustment in mitigation measures based } \\
\text { on monitoring results, which could result in either less or more stringent } \\
\text { mitigation measures. }\end{array}$ \\
\hline 3 & Smøla Wind Farm & Norway & $\begin{array}{l}68 \text { wind turbines, } 150 \mathrm{MW} \\
\text { capacity }\end{array}$ & $\begin{array}{l}\text { Operational, moving } \\
\text { toward repowering }\end{array}$ & $\begin{array}{l}\text { 1. White-tailed eagle collisions of greatest concern, also those of other bird species. } \\
\text { 2. An adaptive management approach used, in assessing needs for repowering. } \\
\text { 3. Research is conducted on efficacy of updraft-based micro-siting of turbines } \\
\text { (which was tested at another wind farm on the neighboring island of Hitra), } \\
\text { painting blades and towers for better visibility, deterrence around turbines with } \\
\text { ultraviolet (UV) lighting, and selective curtailment. }\end{array}$ \\
\hline
\end{tabular}


Table 3. Cont

\begin{tabular}{|c|c|c|c|c|c|}
\hline Case & Number and Name & Country & $\begin{array}{l}\text { Description of } \\
\text { Development }\end{array}$ & Stage of Development & Management Actions \\
\hline 4 & $\begin{array}{c}\text { Candeeiros Wind } \\
\text { Farm, } \\
\text { Alcobaça/Rio } \\
\text { Maior }\end{array}$ & Portugal & $\begin{array}{l}42 \text { turbines, } 121 \mathrm{MW} \text {, } \\
\text { estimated annual } \\
\text { production of } 345 \mathrm{GW}\end{array}$ & Operational, repowering & $\begin{array}{l}\text { 1. Post-construction monitoring showed high fatality rate of common kestrels. } \\
\text { 2. Mitigation to decrease attractiveness of the areas around the turbines and to } \\
\text { increase food availability in areas outside the wind farm. } \\
\text { 3. Adaptive management was used, resulting in monitoring data that showed a } \\
\text { decrease in kestrel collisions, increased tracking of individuals with Global } \\
\text { Positioning System (GPS), and further changes in vegetation management } \\
\text { around turbines. }\end{array}$ \\
\hline 5 & $\begin{array}{c}\text { Swiss Jura } \\
\text { mountains, } 13 \\
\text { distinct projects }\end{array}$ & Switzerland & $\begin{array}{c}145 \text { wind turbines, spread } \\
\text { over } 2000 \mathrm{~km}^{2}\end{array}$ & $\begin{array}{l}\text { Studies under way to } \\
\text { support consenting and } \\
\text { development }\end{array}$ & $\begin{array}{l}\text { 1. Sensitivity mapping is being used to identify important sites for birds and bats, } \\
\text { and to exclude wind energy development. } \\
\text { 2. Priority areas for wind energy development and the level of conflict potential for } \\
\text { nesting and migratory birds across the region are being identified. } \\
\text { 3. Studies of bats and birds, including nesting habitats and buffers, and predictive } \\
\text { modeling for song birds' migratory routes are being conducted. } \\
\text { 4. Collision risk and population modeling is being conducted to determine } \\
\text { cumulative risks to protected bird and bat species. } \\
\text { 5. Mitigation measures are being used to reduce population-level impacts. } \\
\text { 6. A stakeholder steering committee monitors wind project development and } \\
\text { 7. } \begin{array}{l}\text { Mildige impacts. } \\
\text { exceed predictions. }\end{array}\end{array}$ \\
\hline 6 & $\begin{array}{l}\text { Moray Firth } \\
\text { Offshore Wind } \\
\text { Projects, which } \\
\text { entails } 3 \text { projects }\end{array}$ & $\begin{array}{l}\text { United } \\
\text { Kingdom }\end{array}$ & $\begin{array}{ll}\text { 1. } & \text { Beatrice: } 84 \times 7 \\
& \text { MW turbines } \\
\text { 2. } & \text { Moray East: } 950 \\
& \text { MW } \\
\text { installed capacity } \\
\text { 3. } & \begin{array}{l}\text { Moray West: under } \\
\text { initial consultation }\end{array}\end{array}$ & $\begin{array}{l}\text { 1. } \begin{array}{l}\text { Under construction, } \\
\text { first electricity } \\
\text { generation in 2018, } \\
\text { fully operational } \\
\text { in } 2019\end{array} \\
\text { 2. } \begin{array}{l}\text { Consented in 2014, } \\
\text { construction } \\
\text { scheduled to } \\
\text { begin } 2019\end{array} \\
\text { 3. } \begin{array}{l}\text { Under initial } \\
\text { consultation with an }\end{array} \\
\text { Environmental } \\
\text { Impact Statement } \\
\text { scheduled to be } \\
\text { submitted for public } \\
\text { consultation in } 2018 .\end{array}$ & $\begin{array}{l}\text { 1. Initial zonal assessment identified the Moray Firth area for offshore wind farm } \\
\text { development based on GIS mapping that included a large number of constraints } \\
\text { (including information about seabirds and marine mammals). } \\
\text { 2. Each project assesses worst-case scenario cumulative impacts at the population } \\
\text { level for potentially affected marine mammal and seabird populations. } \\
\text { 3. Mitigation measures are incorporated through the Environmental Impact } \\
\text { Assessment process to reduce the risks; e.g., use of acoustic deterrent devices } \\
\text { (ADDs) prior to pile driving to reduce the likelihood of marine mammals being } \\
\text { injured by acoustics, use of fewer and larger turbines to decrease risks of collision } \\
\text { and displacement effects on seabirds. } \\
\text { A. Regional Advisory Group (RAG), made up of key stakeholders, agreed upon } \\
\text { question-based monitoring that is undertaken by the project developers. The } \\
\text { results can inform future worst-case scenario cumulative effects assessment, } \\
\text { making it less precautionary and more accurate. }\end{array}$ \\
\hline
\end{tabular}


Table 3. Cont

\begin{tabular}{|c|c|c|c|c|c|}
\hline Case & Number and Name & Country & $\begin{array}{l}\text { Description of } \\
\text { Development }\end{array}$ & Stage of Development & Management Actions \\
\hline 7 & $\begin{array}{l}\text { Sierra de los } \\
\text { Caracoles Wind } \\
\text { Farm }\end{array}$ & Uruguay & $\begin{array}{l}5 \text { turbines, } 10 \mathrm{MW} \\
\text { capacity, } \\
\text { additional } 5 \text { turbines } \\
\text { proposed, } 10 \text { MW capacity }\end{array}$ & Operational and planning & $\begin{array}{l}\text { 1. Greatest concerns are over visual impacts and cultural resources. Other risks from } \\
\text { the wind farm are not clear but will be determined by monitoring. } \\
\text { 2. Phased development, adaptive management, and landscape-scale management } \\
\text { are in use. } \\
\text { 3. With the initial } 5 \text { turbines, monitoring will determine effects on birds and bats. } \\
\text { 4. A phased approach will determine how } 5 \text { more turbines will be added, based on } \\
\text { monitoring of the first } 5 \text {. } \\
\text { 5. Explicit mention of need to reduce scientific uncertainty. }\end{array}$ \\
\hline 8 & Block Island & $\begin{array}{l}\text { United } \\
\text { States }\end{array}$ & $\begin{array}{l}\text { First offshore wind farm } \\
\text { in North America. Five } \\
\text { seabed-mounted turbines, } \\
\text { each } 6 \mathrm{MW} \text {. }\end{array}$ & Operational & $\begin{array}{l}\text { 1. Siting and planning: Sited in wind energy area determined by the State of Rhode } \\
\text { Island through the Ocean Special Area Management Plan. } \\
\text { 2. Studies: Extensive baseline studies and post-installation monitoring of benthic } \\
\text { habitats, birds, and bats. } \\
\text { 3. Habitat protection: Horizontal direct drilling for cable through shallow water and } \\
\text { intertidal area. } \\
\text { 4. Construction: Monitoring for sound of piling at sea and additional vessel traffic. } \\
\text { 5. Operation. Turbines curtailed during fog. }\end{array}$ \\
\hline 9 & $\begin{array}{l}\text { Cape Wind Energy } \\
\text { Project, Nantucket } \\
\text { Sound }\end{array}$ & $\begin{array}{l}\text { United } \\
\text { States }\end{array}$ & $\begin{array}{c}130 \text { turbines, } 468 \mathrm{MW} \\
\text { capacity }\end{array}$ & $\begin{array}{l}\text { Planning and consenting } \\
\text { process. Cancelled. }\end{array}$ & $\begin{array}{l}\text { 1. Adaptive management approach to monitoring and mitigation through Avian } \\
\text { and Bat Mitigation and Monitoring Plan (ABMP). } \\
\text { 2. Mitigation plan focused largely on construction activities, including underwater } \\
\text { noise reduction, marine mammal observers on vessels during pile driving, etc. } \\
\text { 3. Broad consultation with stakeholders including Native American Tribes. }\end{array}$ \\
\hline 10 & $\begin{array}{l}\text { Iowa Wind Energy } \\
\text { Project Portfolio, } \\
\text { Iowa }\end{array}$ & $\begin{array}{l}\text { United } \\
\text { States }\end{array}$ & $\begin{array}{l}22 \text { wind energy facilities } \\
\text { with } 2020 \text { turbines, greater } \\
\text { than } 4040 \text { MW capacity }\end{array}$ & Operational & $\begin{array}{l}\text { 1. Ecological approach, including adaptive management using a Habitat } \\
\text { Conservation Plan (HCP) that focuses on bats and bald eagles under special } \\
\text { protection; applying mitigation hierarchy to ensure these populations are not } \\
\text { affected; and protection and monitoring for other bat species and their habitats. } \\
\text { The projects examined as part of this analysis also provide financial assistance for } \\
\text { costs of monitoring and mitigation. } \\
\text { 3. The adaptive management applies monitoring results to verify the effectiveness of } \\
\text { mitigation measures and to reduce the uncertainty of wind energy effects in Iowa; } \\
\text { and triggers additional monitoring and mitigation if annual collision mortality } \\
\text { exceeds defined threshold limits. } \\
\text { The adaptive management framework allows for reduced mitigation measures if } \\
\text { monitoring results show lower mortality than allowed, including less stringent } \\
\text { mitigation measures such as blade feathering below the normal turbine cut-in } \\
\text { wind speed. }\end{array}$ \\
\hline
\end{tabular}


Table 4. Assessment of the ability for each case study to validate risk-based management goals, by development phase. Key management actions are assessed against the objectives of the wind-wildlife RBM framework.

\begin{tabular}{|c|c|c|c|c|c|c|c|c|c|c|}
\hline & $\begin{array}{c}\text { Case } 1 \\
\text { Crudine } \\
\text { Ridge }\end{array}$ & $\begin{array}{l}\text { Case } 2 \\
\text { Norther }\end{array}$ & $\begin{array}{l}\text { Case } 3 \\
\text { Smøla }\end{array}$ & $\begin{array}{c}\text { Case } 4 \\
\text { Candeeiros }\end{array}$ & $\begin{array}{c}\text { Case } 5 \\
\text { Jura } \\
\text { Mountains } \\
\end{array}$ & $\begin{array}{c}\text { Case } 6 \\
\text { Moray Firth }\end{array}$ & $\begin{array}{c}\text { Case } 7 \\
\text { Sierra de los } \\
\text { Caracoles }\end{array}$ & $\begin{array}{l}\text { Case } 8 \\
\text { Block } \\
\text { Island } \\
\end{array}$ & $\begin{array}{c}\text { Case } 9 \\
\text { Cape Wind }\end{array}$ & $\begin{array}{c}\text { Case 10 } \\
\text { Iowa Wind } \\
\text { Energy }\end{array}$ \\
\hline $\begin{array}{l}\text { Development } \\
\text { Phase }\end{array}$ & $\begin{array}{c}\text { Under } \\
\text { Construction }\end{array}$ & $\begin{array}{l}\text { Siting and } \\
\text { Permitting, } \\
\text { Construction, } \\
\text { Operational }\end{array}$ & $\begin{array}{l}\text { Operational, } \\
\text { Planning for } \\
\text { Repowering }\end{array}$ & Operational & $\begin{array}{l}\text { Studies to } \\
\text { Support } \\
\text { Consenting }\end{array}$ & $\begin{array}{l}\text { Operational, } \\
\text { Consented, } \\
\text { Consenting } \\
\text { Consultation }\end{array}$ & $\begin{array}{l}\text { Operational } \\
\text { and Planned }\end{array}$ & $\begin{array}{l}\text { Siting and } \\
\text { Permitting, } \\
\text { Construction, } \\
\text { Operational }\end{array}$ & $\begin{array}{l}\text { Planning, } \\
\text { Siting and } \\
\text { Permitting } \\
\text { (Cancelled) }\end{array}$ & Operational \\
\hline Sustainability & $X X$ & $x$ & $x X$ & - & $X X$ & $X X$ & $x$ & $x$ & - & $x$ \\
\hline $\begin{array}{l}\text { Ecological } \\
\text { health }\end{array}$ & $X X$ & $X X$ & - & - & - & - & $X X$ & - & $x$ & $x$ \\
\hline $\begin{array}{l}\text { Humans in } \\
\text { ecosystem }\end{array}$ & $x$ & $x$ & $x$ & $x$ & $x x$ & $x$ & $X X$ & $x$ & $x$ & - \\
\hline Complexity & - & $x$ & - & - & - & $x$ & $x$ & - & - & - \\
\hline Temporal & $x$ & $X X$ & $X X$ & $X X$ & $x$ & $X X$ & $x$ & $x$ & $X X$ & $X X$ \\
\hline Spatial & $X X$ & $X X$ & $X X$ & $x$ & $X X$ & $X X$ & $x$ & $x$ & $x$ & $X X$ \\
\hline Economics & - & - & - & - & - & - & - & $X X$ & - & $X X$ \\
\hline Stakeholders & $x$ & $x$ & - & $x$ & $x$ & $x$ & $x$ & $x$ & $x$ & $x$ \\
\hline Science-based & $x$ & $X X$ & $X X$ & $x$ & $x$ & $X X$ & $x X$ & $x$ & $X X$ & $x$ \\
\hline Techno-logical & - & $X X$ & $X X$ & - & - & - & $x$ & $x$ & $x X$ & $x$ \\
\hline Adaptive & $X X$ & $X X$ & $x$ & $X X$ & $X X$ & $x$ & $X X$ & $X X$ & $x$ & $X X$ \\
\hline
\end{tabular}




\section{Discussion}

The RBM framework was adapted from EBM criteria as a means of examining the range and application of studies, monitoring foci, and mitigation measures that are prevalent in wind farm development around the world, through a set of wind energy case studies. The intent was not to demonstrate that certain countries, or certain types of wind farms, are most closely aligned with the principles and implementation of RBM, but rather to examine how wind energy development may potentially use RBM to further the goal of ensuring that low-carbon wind energy development can proceed while protecting fragile local and regional environments. Some deficiencies and challenges become clear from the assessment of the case studies including the difficulty in assessing wind effects on wildlife in time and space, as well as constraints that may arise in implementing RBM at land-based and offshore wind farms. In addition, the examination of the cases within the framework suggest some recommended actions and best practices to support wind-wildlife interactions at wind energy farms.

Collection of data around wind farms is inherently difficult due to the extensive natural variability of wildlife populations and habitats to change. In contrast to the typical species-by-species wind farm management, ecological RBM encourages consideration of ecological interactions between and among populations, habitats, and ecosystem functions [58]. The RBM wind-wildlife framework applies the criteria of sustainability, ecological health, ecosystem services, and complexity to examine these interactions (Table 2). Although many of the wind case studies (Table 3) considered aspects of the environment beyond species under special protection, there was little focus on understanding the complexity and interactivity of other animals, plants, and ecosystem processes that support those populations. Similarly, virtually no consideration was given to predator-prey interactions, or species competing for food or spatial resources, nor was much emphasis placed on examining temporal and spatial home ranges of importance to wildlife [59].

Based on many of the case studies, wind farm monitoring programs are often driven by regulatory requirements that are not necessarily underpinned by scientific questions. Each of the cases applies some of the principles of adaptive management, indicating a desire to examine and decrease scientific uncertainty. However, there is room for improvement for all the cases in applying scientific principles to the collection and analysis of data, beginning with the design of sampling plans, examination of appropriate sampling intervals to capture changes in life history and seasonal signals, trophic interactions, and effects of external factors such as weather patterns and changing climates. Particularly evident was the paucity of studies to address questions related to the potential effects on ecosystem structure, function, and services, as has been shown in other studies [60,61].

The RBM wind-wildlife framework was developed to embrace the values of the EBM process, and modified to reflect wind farm management. Developing a framework that is usable for land-based and offshore wind cases is complicated by the high level of heterogeneity that exists between geographic locations, indigenous, and migratory wildlife species, national laws and regulations, stakeholder interests, regional, and intercontinental migratory corridors, and national/international financial incentives for development. The framework reflects these complications and, of necessity, tends toward generalizations in describing the desired outcomes of an RBM system.

Wind farm development creates challenges and constraints to meeting some of the criteria for the wind-wildlife RBM framework. For example, there will be a need to collect additional baseline and monitoring data year-round; engage stakeholder facilitators; and bring together a large and diverse scientific team with expertise in wildlife, habitats, ecosystem processes, economic, and other human uses, and ecological integrity. Each of these constraints will add to the cost of preparing for, constructing, and operating a wind farm. To implement an RBM approach, it may be necessary for governments and regional authorities to provide public resources to ensure that native species and habitats are protected while developing new low-carbon energy sources. Shared responsibilities and costs between the private developer and the public entities offer the best chance of success for protecting environmental assets and producing power (cf. [62,63]. 


\subsection{Recommendations for Environmental RBM for Wind Energy Development}

Based on the case studies, recommendations for implementing RBM include the need to consider the complexity of the ecological interactions in monitoring data collection; applying planning and management tools to decrease risk; inclusion of stakeholders in planning and outcomes; and focusing on social and economic outcomes. Although regulatory requirements will always drive what is asked of wind farm developers, there is a need ensure that the data collection, analysis, and mitigation measures are science-driven, such that data and mitigation efforts will be proportionate to the risk to the ecological system, and the addition of these data to the public record will lead to a decrease in scientific uncertainty around these interactions [63].

\subsection{Addressing Complexity of Ecological Interactions}

The complexity of the ecological system in the vicinity of the project should drive the data collection, modeling, and analysis efforts. In many cases, the more complex relationships (like predator-prey interactions and other ecosystem responses) may be beyond the scope of a single wind farm and should be undertaken by national or regional governments to aid in planning for future wind energy expansion. Measures are needed to enhance and enable wind energy development to address necessary and challenging aspects of RBM, and also to evaluate the effectiveness of applying RBM, as measured by positive outcomes for wind energy development and interactions with the ecosystem. For land-based and offshore wind energy development, these measures include the need for robust assessments prior to development for populations and habitats that have a reasonable likelihood of being affected by development and operation of a wind farm. In addition, post-installation monitoring must be driven by hypothesis-based questions for interactions and population health, that also direct the development and implementation of mitigation for potential deleterious effects. Each step in the process (baseline assessment, post-installation monitoring, and mitigation) should be evaluated periodically, using adaptive processes for change when needed.

\subsection{Using the Mitigation Hierarchy and Adaptive Management to Manage Wind Farms}

Incorporating adaptive management principles into an RBM process to enable the wind farm operator, regulators, and other stakeholders will enable enhanced understanding of the effects of the wind farm, and allow for mid-course corrections in data collection, analysis, and mitigation.

Mitigation measures for wind farms are commonly thought of as ways to decrease adverse effects, generally after construction or operation has begun [35]. Under RBM it is also prudent to consider design, siting, and operational plans as means of decreasing risk through avoidance. A key element of decreasing ecological risk for land-based wind is the micro-siting of turbines within a wind farm to ensure the least impact on key species and habitats. The mitigation measures described in each case vary by the location and size of the wind project, species of concern, and whether the wind farm is land-based or offshore. Typically, mitigation measures among the land-based wind farms include measures to decrease the impacts of road building and other construction-related activities, as well as curtailment or other operational changes to decrease collision risk. A few cases include other operational measures, such as painting towers for increased wildlife visibility, as in the Smøla case study. Offshore wind farm mitigation is most attuned to decreasing the effects of construction, such as underwater noise and increased vessel traffic, and virtually no curtailment or other operational changes have been used to date [64]. In managing land-based and offshore wind farm case studies, monitoring results should be reevaluated and monitoring efforts realigned to act as mitigation measures, particularly in the pursuit of decreasing scientific uncertainty, supporting RBM principles.

Only a few of the case studies specifically required the development and implementation of AM plans aimed at protecting populations at risk, and virtually none considered additional aspects of the ecosystem. Most notably missing from the application of AM were measurable feedback loops that would apply outcomes from mortality and population monitoring data to the broader ecosystem. 
In an ideal application, changes in populations from wind farm collisions or other likely effects would trigger increased monitoring of related species (predators, prey, competitors), linked habitats and migratory corridors, and (particularly at sea) ecosystem processes like circulation and sediment transport. Adaptive processes must also allow for decreases in monitoring and mitigation efforts if monitoring data indicate a lower than anticipated risk to species under special protection and the habitats that support them.

\subsection{Inclusion of Stakeholders}

In almost all jurisdictions, stakeholders must be allowed to play a role in some aspect of consenting and licensing wind farms. Most public involvement focuses on the opportunity for stakeholders to provide input and comment on plans and procedures prior to authorities granting permission to site and construct a wind farm. A smaller number of the case studies represent a more integrated stakeholder approach throughout the life of the wind farm. Notably, the Jura mountains wind farms require a committee of stakeholders who meet to review monitoring data and help to set operating specifications for future periods. For several of the wind farm cases, the proponents exceeded the legally required stakeholder engagement, understanding that consulting with affected stakeholders and the general public early and often helps to reduce opposition to the development, and can often generate useful suggestions and good will. Under the RBM framework developed here, the engagement of stakeholders is necessary above and beyond what specific laws or regulations require.

\subsection{Social and Economic Outcomes}

Ecological risk is unavoidably linked to social acceptance of wind farm development. Opposition and support for wind development often hinges on perceptions of risks or benefits that will accrue to local communities and regions [63]. Many of the concerns are associated with the proximity of stakeholder properties and activities to proposed wind farms, including visual effects. In general, stakeholders object less to offshore wind farms than those on land [65]. It is very common for opposition to wind farms to be presented as a concern about environmental risk, even if underlying social and economic issues are at the base of the concern. By addressing social and economic issues alongside the environmental issues, there is an opportunity to counteract opposition to wind energy development, while ensuring that local communities are respected and kept informed of the plans and outcomes of the development.

\subsection{Best Management Practices for the Application of Risk-Based Management to Wind Energy Development}

At the initial development stage for a wind farm, the RBM context should be considered, including the development of a series of best management practices:

- Examining criteria that support ecological integrity and manage risk to the environment, working with the stakeholders.

- Measuring the criteria against proposed actions.

- Determining whether the proposed wind development actions are unlikely to meet the needs of a healthy environment.

- Empowering the wind farm proponent, regulators, and stakeholders to collectively determine the definition of environmental health in the presence of wind farms.

Authors should discuss the results and how they can be interpreted in perspective of previous studies and of the working hypotheses. The findings and their implications should be discussed in the broadest context possible. Future research directions may also be highlighted.

\section{Conclusions}

The examination of risk-based tools and management structures leads to the conclusion that management of land-based and offshore wind farms can be enhanced by deploying wind energy projects concurrent with risk identification and mitigation. While ecological risk is the subject of this 
paper, a cascading set of risks are associated with or directly affected by ecological risk, most notably different aspects of financial and reputational risk [32].

Although there are arguably many different ways to view and evaluate risk [32] provides a subset of these), the authors believe that EBM provides the most useful set of indicators related to wind farm development and operation. The EBM-influenced wind-wildlife framework is designed to deliver the most pertinent measures of how wind energy development might fit into a risk-based system. Collection of data around wind farms is inherently difficult and wind farm monitoring programs are often driven by regulatory requirements that are not necessarily underpinned by scientific questions. The RBM wind-wildlife framework applies the criteria of sustainability, ecological health, ecosystem services, and complexity to examine and underpin environmental interactions.

The wind farm case studies provide a snapshot of the range of land-based and offshore wind farms, covering most phases of development. Developing a framework that is usable for land-based and offshore wind cases is complicated by the high level of heterogeneity that range from biogeographic, to wildlife species and communities, to financial and legal imperatives. The cases presented in this paper are therefore likely not to be representative of all wind farms, nor are they intended to show all possible risk-based evaluations and management actions for any particular type of wind energy development. Even so, we can glean from the cases how construction and operational mitigation measures for wind farms are being used in practice to decrease adverse outcomes. Under this framework, mitigation can be viewed as extending to the design, siting, and wildlife avoidance measures.

Stakeholder engagement and the inclusion of stakeholder concerns at an early stage of consenting and licensing wind farms is fundamental to gaining social acceptance and putting into perspective the perceptions of risks or benefits for local communities. Similarly, at the conception of a wind farm project, the application of best practices for wind-wildlife interactions can help to defray concerns from communities over ecological damage, even if some of those concerns are more correctly social and economic concerns.

The examination of case studies and the development of the RBM framework are first steps in operationalizing the application of risk-based wind energy development. More detail is needed to guide implementation of RBM from the general to the specific scale. A series of best practices is offered here as a start; application of these best practices and the specifics of assessments, monitoring, and mitigation plans that decrease scientific uncertainty and provide large-scale protection to living resources must be tailored to each geographic region and each set of national goals for renewables development and environmental protection.

Author Contributions: Conceptualization: A.E.C., R.M., F.B. and E.D.; methodology: A.E.C., R.M., F.B. and E.D.; formal analysis: A.E.C., A.M.G., R.M., F.B., E.D., M.R.G. and B.R.; writing-original draft preparation: A.E.C., A.M.G., R.M., F.B., E.D., M.R.G. and B.R.; writing-review and editing: A.E.C., A.M.G., R.M., F.B., E.D., M.R.G. and B.R.; project administration: A.M.G.; funding acquisition: A.E.C. All authors have read and agreed to the published version of the manuscript.

Funding: Support for the development of this paper came from the U.S. Department of Energy to Pacific Northwest National Laboratory, operated by Battelle for the United States Department of Energy under Contract DE-AC05-76RL01830.

Acknowledgments: This paper was developed under the International Energy Agency (IEA) Wind Implementing Agreement for Co-operation in the Research, Development, and Deployment of Wind Energy Systems Task 34: Working Together to Resolve Environmental Effects of Wind Energy (WREN). Assistance in paper formulation, drafting, and review was provided by participating WREN member nations including Germany, the Netherlands, Norway, Switzerland, the United Kingdom, and the United States. The advice and involvement of the federal partners in WREN-Mary Boatman and Brian Hooper (Bureau of Ocean Energy Management), Candace Nachman (National Oceanic and Atmospheric Administration), and Rachel London (US Fish and Wildlife Service) - helped to improve the focus and outcome of the paper. We extend our gratitude to all those who have assisted and supported the development of this paper including Hayley Farr and Susan Ennor of PNNL. In particular, we thank those who contributed case studies, whose insight and experiences were critical to developing this paper. The authors also thank the reviewers of the paper who provided valuable insights and input, and those who shared their international experiences with adaptive management. We are also very grateful to the anonymous peer reviewers who provided useful comments, additional information, and wise insights.

Conflicts of Interest: The authors declare no conflict of interest. 


\section{References}

1. Edenhofer, O.R.; Pichs-Madruga, Y.; Sokona, K.; Seyboth, P.; Matschoss, S.; Kadner, T.; Zwickel, P.; Eickemeier, G.; Hansen, S.; Schloemer, C.; et al. Renewable Energy Sources and Climate Change Mitigation; Cambridge University Press: Cambridge, UK; International Panel on Climate Change (IPCC): New York, NY, USA, 2011; p. 1075.

2. Gee, K.; Kannen, A.; Adlam, R.; Brooks, C.; Chapman, M.; Cormier, R.; Fischer, C.; Fletcher, S.; Gubbins, M.; Shucksmith, R.; et al. Identifying culturally significant areas for marine spatial planning. Ocean Coast. Manag. 2017, 136, 139-147. [CrossRef]

3. Gerkensmeier, B.; Ratter, B.M.W. Multi-risk, multi-scale and multi-stakeholder-The contribution of a bow-tie analysis for risk management in the trilateral Wadden Sea Region. J. Coast. Conserv. 2018, 22, 145-156. [CrossRef]

4. Gill, A.B.; Wilhelmsson, D. Fish. In Wildlife and Wind Farms: Conflicts and Solutions. Volume 3 Offshore: Potential Effects; Perrow, M., Ed.; Pelagic Publishing: Exeter, UK, 2019; 250p.

5. Nehls, G.; Harwood, A.J.P.; Perrow, M. Marine Mammals. In Wildlife and Wind Farms: Conflicts and Solutions. Volume 3 Offshore: Potential Effects; Perrow, M., Ed.; Pelagic Publishing: Exeter, UK, 2019; 250p.

6. Hüppop, O.B.; Michalik, L.; Bach, R.; Hill, S.K. Migratory Birds and Bats. In Wildife and Wind Farms: Conflicts and Solutions. Volume 3 Offshore: Potential Effects; Perrow, M., Ed.; Pelagic Publishing: Exeter, UK, 2019; 250p.

7. Vanermen, N.; Stienen, E.W.M. Seabirds: Displacement. In Wildlife and Wind Farms: Conflicts and Solutions. Volume 3 Offshore: Potential Effects; Perrow, M., Ed.; Pelagic Publishing: Exeter, UK, 2019; 250p.

8. Barclay, R.M.; Baerwald, E.; Gruver, J. Variation in bat and bird fatalities at wind energy facilities: Assessing the effects of rotor size and tower height. Can. J. Zool. 2007, 85, 381-387. [CrossRef]

9. Marques, A.T.; Batalha, H.; Rodrigues, S.M.M.; Costa, H.; Pereira, M.J.R.; Fonseca, C.; Mascarenhas, M.; Bernardino, J. Understanding bird collisions at wind farms: An updated review on the causes and possible mitigation strategies. Biol. Conserv. 2014, 179, 40-52. [CrossRef]

10. Thaxter, C.B.; Buchanan, G.; Carr, J.; Butchart, S.H.M.; Newbold, T.; Green, R.E.; Tobias, J.A.; Foden, W.; O'Brien, S.; Pearce-Higgins, J.W. Bird and bat species' global vulnerability to collision mortality at wind farms revealed through a trait-based assessment. Proc. R. Soc. B Boil. Sci. 2017, 284, 20170829. [CrossRef] [PubMed]

11. Kuvlesky, W.P.; Brennan, L.A.; Morrison, M.L.; Boydston, K.K.; Ballard, B.M.; Bryant, F.C. Wind Energy Development and Wildlife Conservation: Challenges and Opportunities. J. Wildl. Manag. 2007, 71, 2487-2498. [CrossRef]

12. May, R.F. A unifying framework for the underlying mechanisms of avian avoidance of wind turbines. Biol. Conserv. 2015, 190, 179-187. [CrossRef]

13. Kunz, T.H.; Arnett, E.B.; Erickson, W.P.; Hoar, A.R.; Johnson, G.D.; Larkin, R.P.; Strickland, M.D.; Thresher, R.W.; Tuttle, M.D. Ecological impacts of wind energy development on bats: Questions, research needs, and hypotheses. Front. Ecol. Environ. 2007, 5, 315-324. [CrossRef]

14. Pelc, R.; Fujita, R.M. Renewable energy from the ocean. Mar. Policy 2002, 26, 471-479. [CrossRef]

15. Lovich, J.E.; Ennen, J.R. Assessing the state of knowledge of utility-scale wind energy development and operation on non-volant terrestrial and marine wildlife. Appl. Energy 2013, 103, 52-60. [CrossRef]

16. Hüppop, O.; Dierschke, J.; Exo, K.-M.; Fredrich, E.; Hill, R. Bird migration studies and potential collision risk with offshore wind turbines. Ibis 2006, 148, 90-109. [CrossRef]

17. Brabant, R.; Vanermen, N.; Stienen, E.W.M.; Degraer, S. Towards a cumulative collision risk assessment of local and migrating birds in North Sea offshore wind farms. Hydrobiol. 2015, 756, 63-74. [CrossRef]

18. Tomsen, F.; Lüdemann, K.; Kafemann, R.; Piper, W. Effects of Offshore Wind Farm Noise on Marine Mammals and Fish; Report by Collaborative Offshore Wind Research into the Environment (COWRIE); COWRIE (Cooperative Offshore Wind Research into the Environment): Hamburg, Germany, 2006; p. 62.

19. Baeye, M.; Fettweis, M. In situ observations of suspended particulate matter plumes at an offshore wind farm, southern North Sea. Geo-Marine Lett. 2015, 35, 247-255. [CrossRef]

20. Vallejo, G.C.; Grellier, K.; Nelson, E.J.; McGregor, R.M.; Canning, S.J.; Caryl, F.M.; McLean, N. Responses of two marine top predators to an offshore wind farm. Ecol. Evol. 2017, 7, 8698-8708. [CrossRef] [PubMed]

21. Vanermen, N.; Onkelinx, T.; Courtens, W.; Van De Walle, M.; Verstraete, H.; Stienen, E.W.M. Seabird avoidance and attraction at an offshore wind farm in the Belgian part of the North Sea. Hydrobiol. 2014, 756, 51-61. [CrossRef] 
22. Dierschke, V.; Furness, R.W.; Garthe, S. Seabirds and offshore wind farms in European waters: Avoidance and attraction. Biol. Conserv. 2016, 202, 59-68. [CrossRef]

23. Wilding, T.A.; Gill, A.B.; Boon, A.; Sheehan, E.; Dauvin, J.; Pezy, J.-P.; O’Beirn, F.; Janas, U.; Rostin, L.; De Mesel, I. Turning off the DRIP ('Data-rich, information-poor')—Rationalising monitoring with a focus on marine renewable energy developments and the benthos. Renew. Sustain. Energy Rev. 2017, 74, 848-859. [CrossRef]

24. Cardona, O.-D.; Van Aalst, M.K.; Birkmann, J.; Fordham, M.; McGregor, G.; Perez, R.; Pulwarty, R.S.; Schipper, E.L.F.; Sinh, B.T.; Décamps, H.; et al. Determinants of Risk: Exposure and Vulnerability. In Managing the Risks of Extreme Events and Disasters to Advance Climate Change Adaptation; A Special Report of Working Groups I and II of the Intergovernmental Panel on Climate Change (IPCC); Field, C.B., Ed.; Cambridge University Press: Cambridge, UK; New York, NY, USA, 2012; pp. 65-108.

25. ISO (International Standards Organisation). Risk Management_Guidelines; ISO 31000:2018-02(E); ISO (International Standards Organisation): Geneva, Switzerland, 2018.

26. IFC (International Finance Corporation). Good Practice Handbook Cumulative Impact Assessment and Management: Guidance for the Private Sector in Emerging Markets; International Finance Corporation: Washington, DC, USA, 2013; 102p.

27. Cormier, R.; Londsdale, J. Risk assessment for deep sea mining: An overview of risk. Mar. Policy 2020, 114, 103485. [CrossRef]

28. Stelzenmüller, V.; Coll, M.; Mazaris, A.D.; Giakoumi, S.; Katsanevakis, S.; Portman, M.E.; Degen, R.; Mackelworth, P.; Gimpel, A.; Albano, P.G.; et al. A risk-based approach to cumulative effect assessments for marine management. Sci. Total. Environ. 2018, 612, 1132-1140. [CrossRef]

29. Cormier, R.; Kannen, A.; Elliott, M.; Hall, P. Marine Spatial Planning Quality Management System. ICES Coop. Res. Rep. 2015, 327, 111.

30. Gregory, R.; Failing, L.; Harstone, M.; Long, G.; McDaniels, T.; Ohlson, D. Structural Decision Making; A Practical Guide to Environmental Management Choices; Wiley: Blackwell West Sussex, UK, 2012.

31. Hanssen, F.; May, R.; Van Dijk, J.; Rød, J.K. Spatial Multi-Criteria Decision Analysis Tool Suite for Consensus-Based Siting of Renewable Energy Structures. J. Environ. Assess. Policy Manag. 2018, 20. [CrossRef]

32. Copping, A.; Gorton, A.; May, R.; Bennet, F.; de George, E.; Repas Goncalves, M.; Rumes, B. IEA Wind White Paper on A Risk-Based Approach for Addressing Wind and Wildlife Interactions Using Ecosystem-Based Management Values. Prep. Int. Energy Agency Wind Implement. Agreem. Task 2020, 34, 67.

33. Sinclair, K.; Copping, A.E.; May, R.; Bennet, F.; Warnas, M.; Perron, M.; Elmqvist, Å.; DeGeorge, E. Resolving environmental effects of wind energy. Wiley Interdiscip. Rev. Energy Environ. 2018, 7, e291. [CrossRef]

34. Copping, A.; Gartman, V.; May, R.; Bennet, F. The Role of Adaptive Management in the Wind Energy Industry. In Wind Energy and Wildlife Impacts: Balancing Energy Sustainability with Wildlife Conservation; Bispo, R., Bernardino, J., Coelho, H., Costa, J.L., Eds.; Springer Nature Publishing AG: Cham, Switzerland, 2019; pp. 1-25.

35. May, R. Mitigation options for birds. In Wildife and Wind Farms: Conflicts and Solutions. Volume 1. Onshore. Part 2: Solutions; Best Practice, Monitoring and Mitigation; Perrow, M., Ed.; Pelagic Publishers, Taylor and Francis: Exeter, UK, 2017.

36. Köppel, J.; Dahmen, M.; Helfrich, J.; Schuster, E.; Bulling, L. Cautious but Committed: Moving Toward Adaptive Planning and Operation Strategies for Renewable Energy's Wildlife Implications. Environ. Manag. 2014, 54, 744-755. [CrossRef] [PubMed]

37. Ricci, P.F.; Sheng, H. Benefits and Limitations of the Precautionary Principle. In Reference Module in Earth Systems and Environmental Sciences; Elsevier: Amsterdam, The Netherlands, 2013. [CrossRef]

38. Ashrafi, M.; Davoudpour, H.; Khodakarami, V. Risk assessment of wind turbines: Transition from pure mechanistic paradigm to modern complexity paradigm. Renew. Sustain. Energy Rev. 2015, 51, 347-355. [CrossRef]

39. Nielsen, J.J.; Sørensen, J.D. Methods for Risk-Based Planning of O\&M of Wind Turbines. Energies 2014, 7, 6645-6664.

40. Florian, M.; Sørensen, J.D. Risk-based planning of operation and maintenance for offshore wind farms. Energy Procedia 2017, 137, 261-272. [CrossRef]

41. Staid, A.; Guikema, S.D. Risk Analysis for U.S. Offshore Wind Farms: The Need for an Integrated Approach. Risk Anal. 2015, 35, 587-593. [CrossRef] 
42. Scottish Government. Survey, Deploy and Monitor Licensing Policy Guidance. 2018. Available online: https://www2.gov.scot/Topics/marine/Licensing/marine/Applications/SDM (accessed on 19 October 2020).

43. Copping, A.; Hanna, L.; Van Cleve, B.; Blake, K.; Anderson, R.M. Environmental Risk Evaluation System-An Approach to Ranking Risk of Ocean Energy Development on Coastal and Estuarine Environments. Chesap. Sci. 2014, 38, S287-S302. [CrossRef]

44. Hanna, L.; Copping, A.; Geerlofs, S.; Feinberg, L.; Brown-Saracino, J.; Gilman, P.; Bennet, F.; May, R.; Köppel], J.; Bulling, L.; et al. Assessing Environmental Effects (WREN): Adaptive Management White Paper; Report by Berlin Institute of Technology; Bureau of Ocean Energy Management (BOEM), Marine Scotland Science, Norwegian Institute for Nature Research (NINA), Pacific Northwest National Laboratory (PNNL), and U.S. Department of Energy (DOE): Washington, DC, USA, 2016; p. 46.

45. Long, R.D.; Charles, A.; Stephenson, R.L. Key principles of marine ecosystem-based management. Mar. Policy 2015, 57, 53-60. [CrossRef]

46. Piet, G.; Culhane, F.; Jongbloed, R.; Robinson, L.; Rumes, B.; Tamis, J. An integrated risk-based assessment of the North Sea to guide ecosystem-based management. Sci. Total. Environ. 2019, 654, 694-704. [CrossRef] [PubMed]

47. Christensen, N.; Bartuska, A.; Brown, H.; Carpenter, S.; D’Antonio, C.; Francis, R.; Franklin, J.; MacMahon, J.; Noss, R.; Parsons, D.; et al. The report of the Ecological Society of American Committee on the scientific basis for ecosystem management. Ecol. Appl. 1996, 6, 665-691. [CrossRef]

48. Ruckelshaus, M.; Klinger, T.; Knowlton, N.; DeMaster, D.P. Marine Ecosystem-based Management in Practice: Scientific and Governance Challenges. Bioscience 2008, 58, 53-63. [CrossRef]

49. Barnes, C.; McFadden, K.W. Marine ecosystem approaches to management: Challenges and lessons in the United States. Mar. Policy 2008, 32, 387-392. [CrossRef]

50. Levin, P.S.; Fogarty, M.J.; Murawski, S.A.; Fluharty, D. Integrated Ecosystem Assessments: Developing the Scientific Basis for Ecosystem-Based Management of the Ocean. PLoS Biol. 2009, 7, e1000014. [CrossRef] [PubMed]

51. Samhouri, J.F.; Haupt, A.J.; Levin, P.S.; Link, J.S.; Shuford, R. Lessons learned from developing integrated ecosystem assessments to inform marine ecosystem-based management in the USA. ICES J. Mar. Sci. 2013, 71, 1205-1215. [CrossRef]

52. Ahlborg, H.; Ruiz-Mercado, I.; Molander, S.; Masera, O. Bringing Technology into Social-Ecological Systems Research-Motivations for a Socio-Technical-Ecological Systems Approach. Sustainability 2019, 11, 2009. [CrossRef]

53. Rouillard, J.; Lago, M.; Abhold, K.; Röschel, L.; Kafyeke, T.; Mattheiß, V.; Klimmek, H. Protecting aquatic biodiversity in Europe: How much do EU environmental policies support ecosystem-based management? Ambio 2018, 47, 15-24. [CrossRef]

54. Griffiths, J.C.; Dushenko, W.T. Effectiveness of GIS suitability mapping in predicting ecological impacts of proposed wind farm development on Aristazabal Island, BC. Environ. Dev. Sustain. 2011, 13, 957-991. [CrossRef]

55. Carrete, M.; Sánchez-Zapata, J.A.; Benítez, J.R.; Lobón, M.; Donázar, J.A. Large scale risk-assessment of wind-farms on population viability of a globally endangered long-lived raptor. Biol. Conserv. 2009, 142, 2954-2961. [CrossRef]

56. Arkema, K.K.; Abramson, S.C.; Dewsbury, B.M. Marine ecosystem-based management: From characterization to implementation. Front. Ecol. Environ. 2006, 4, 525-532. [CrossRef]

57. Gardiner, S.M. A Perfect Moral Storm. The Ethical Tragedy of Climate Change; Oxford University Press: New York, NY, USA, 2011.

58. May, R.; Gill, A.B.; Köppel, J.; Langston, R.H.W.; Reichenbach, M.; Scheidat, M.; Smallwood, S.; Voigt, C.C.; Hüppop, O.; Portman, M. Future research directions to reconcile wind-wildlife interactions. In Proceedings of the Conference on Wind Energy and Wildlife Impacts, Berlin 2015, Berlin, Germany, 10-12 March 2015; Köppel, J., Ed.; Springer International Publishing AG: Cham, Switzerland, 2017; pp. 255-276.

59. Burkhard, B.; Opitz, S.; Lenhart, H.; Ahrendt, K.; Garthe, S.; Mendel, B.; Windhorst, W. Ecosystem based modeling and indication of ecological integrity in the German North Sea-Case study offshore wind parks. Ecol. Indic. 2011, 11, 168-174. [CrossRef]

60. Mavraki, N.; Degraer, S.; Moens, T.; Vanaverbeke, J. Functional differences in trophic structure of offshore wind farm communities: A stable isotope study. Mar. Environ. Res. 2020, 157, 104868. [CrossRef] [PubMed] 
61. Mavraki, N.; De Mesel, I.; Degraer, S.; Moens, T.; Vanaverbeke, J. Resource Niches of Co-occurring Invertebrate Species at an Offshore Wind Turbine Indicate a Substantial Degree of Trophic Plasticity. Front. Mar. Sci. 2020, 7. [CrossRef]

62. Stabell, E.D.; Steel, D. Precaution and Fairness: A Framework for Distributing Costs of Protection from Environmental Risks. J. Agric. Environ. Ethic. 2018, 31, 1-17. [CrossRef]

63. May, R. The Mitigation of Impact and the Impact of Mitigation: An Ethical Perspective. In Wind Energy and Wildlife Impacts: Balancing Energy Sustainability with Wildlife Conservation; Bispo, R., Bernardino, J., Coelho, H., Costa, J.L., Eds.; Springer Nature Publishing AG: Cham, Switzerland, 2019; pp. 93-113.

64. Joos, M.; Staffell, I. Short-term integration costs of variable renewable energy: Wind curtailment and balancing in Britain and Germany. Renew. Sustain. Energy Rev. 2018, 86, 45-65. [CrossRef]

65. Jones, C.R.; Eiser, J.R. Understanding 'local' opposition to wind development in the UK: How big is a backyard? Energy Policy 2010, 38, 3106-3117. [CrossRef]

Publisher's Note: MDPI stays neutral with regard to jurisdictional claims in published maps and institutional affiliations.

(C) 2020 by the authors. Licensee MDPI, Basel, Switzerland. This article is an open access article distributed under the terms and conditions of the Creative Commons Attribution (CC BY) license (http://creativecommons.org/licenses/by/4.0/). 